\title{
GRUP HOMOLOGI YANG TEREDUKSI PADA HIMPUNAN KUBIK
}

\author{
SITI MAISYAROH \\ Program Studi Matematika, \\ Fakultas Matematika dan Ilmu Pengetahuan Alam, Universitas Andalas, \\ Kampus UNAND Limau Manis Padang, Indonesia, \\ s.maisya.r@gmail.com
}

\begin{abstract}
Abstrak. Diberikan suatu ruang topologi $X$. Selanjutnya didefinisikan suatu objek aljabar $H_{*}(X)$ yang disebut dengan homologi dari $X$ dan $\left(\tilde{H}_{*}(X)\right)$ yang disebut dengan homologi yang tereduksi dari $X$. Himpunan grup homologi ke- $k$ dari $X$ dinotasikan dengan $H_{k}(X)$ dan $\left(\tilde{H}_{k}(X)\right)$ merupakan himpunan grup homologi ke- $k$ yang tereduksi dari $X . H_{0}(X)$ merupakan grup homologi berdimensi nol yang menyatakan banyaknya connected component pada himpunan kubik tersebut, dimana himpunan titik-titik pada $\left\{P_{i} \mid i=1, \cdots, n\right\}$ pada $X$ terdiri atas satu titik dari masing-masing connected component pada $X$. Pada skripsi ini, dikaji bahwa $H_{k}(X)$ isomorfik dengan $\left(\tilde{H}_{k}(X)\right)$ dimana $k \neq 0$. Koleksi dari rantai dasar $\left[\hat{P}_{i}-\hat{P}_{0}\right] \sim$ yang bersesuaian dengan $P_{i}\left(\left\{\left[P_{i}-P_{0}\right] \sim \in \tilde{H}_{0}(X) \mid i=1, \ldots, n\right\}\right)$ membentuk suatu basis untuk $\left(\tilde{H}_{0}(X)\right)$.
\end{abstract}

Kata Kunci: Ruang topologi, connected component, $\left(\tilde{H}_{0}(X)\right)$, isomorfik

\section{Pendahuluan}

Topologi merupakan cabang matematika yang berkaitan dengan objek-objek geometri yang tidak berubah dalam deformasi dwikontinu (yaitu ruang yang dapat ditekuk, dilipat, disusut, direntangkan, dan dipilin, tetapi tidak diperkenankan untuk dipotong, dirobek, ditusuk atau dilekatkan). Aljabar topologi merupakan suatu konsep yang membahas pengklasifikasian yang sama, tetapi dalam konteks ruang topologi yang didasarkan pada objek aljabar yaitu grup homologi. Misalkan diberikan suatu ruang topologi X. Selanjutnya didefinisikan suatu objek aljabar $H_{*}(X)$ yang disebut dengan homologi dari $X$ yang merupakan sebuah invarian secara topologi, yakni jika $X$ dan $Y$ adalah homeomorpik maka $H_{*}(X)$ dan $H_{*}(Y)$ adalah isomorfik. Hal ini dinotasikan sebagai berikut:

$$
X \approx Y \Longrightarrow H_{*}(X) \cong H_{*}(Y) .
$$

Salah satu masalah yang muncul terkait dengan masalah topologi adalah bagaimana merubah permasalahan topologi menjadi permasalahan aljabar. Misalkan diberikan suatu ruang topologi $G \subset \mathbb{R}^{n}$, yang dapat disederhanakan menjadi suatu graf. Kemudian dilakukan observasi bahwa graf tersebut dapat direpresentasikan secara kombinatorik sehingga diperoleh suatu kuantitas aljabar $H_{*}(G)$ yang disebut homologi dari $G$. 
Sebuah kubik dasar $Q$ adalah suatu hasil kali hingga dari interval-interval dasar $I=[l, l+1]$ atau $I=[l, l]$ untuk suatu $l \in \mathbb{Z}$. Jadi, $Q=I_{1} \times I_{2} \times \cdots \times I_{n} \subset \mathbb{R}^{n}$. Himpunan kubik adalah suatu kelas khusus dari ruang topologi. Untuk itu, himpunan kubik perlu didefinisikan secara jelas. Selanjutnya akan dilanjutkan dengan konsep kombinatorik dan aljabar yang berhubungan dengan ruang ini, dan akhirnya dapat didefinisikan grup homologi pada himpunan kubik. Salah satu grup tersebut adalah grup homologi berdimensi $k\left(H_{k}(X)\right)$ dan grup homologi yang tereduksi yang berdimensi $k\left(\tilde{H}_{k}(X)\right)$.

\section{Grup Homologi yang Tereduksi pada Himpunan Kubik}

Definisi 2.1. [5] Misalkan $X$ adalah himpunan kubik. Rantai kubik yang diperumum pada $X$ dinyatakan dengan $\left\{\tilde{\mathrm{C}}_{k}(X), \tilde{\partial}_{k}\right\}_{k \in \mathbb{Z}}$, dimana

$$
\tilde{\mathrm{C}}_{k}(X)= \begin{cases}\mathbb{Z}, & \text { jika } k=-1 \\ \mathrm{C}_{k}(X), & \text { selainnya }\end{cases}
$$

dan

$$
\tilde{\partial}_{k}:= \begin{cases}\epsilon, & \text { jika } k=0 \\ \partial_{k}, & \text { selainnya } .\end{cases}
$$

Suatu grup homologi $H_{k}(\tilde{\mathcal{C}})(X)$ adalah grup homologi yang tereduksi pada $X$ dan dinotasikan dengan

$$
\tilde{H}_{k}(X)
$$

Teorema berikut menyatakan hubungan antara dua grup homologi.

Teorema 2.2. [5] Misalkan X adalah himpunan kubik dan

$$
H_{k}(X) \cong \tilde{H}_{k}(X) \quad k \neq 0 .
$$

Lebih jauh, jika $\left\{P_{i} \mid i=0,1, \cdots, n\right\}$ adalah koleksi titik-titik pada $X$ yang terdiri dari satu titik dari masing-masing connected component pada $X$, maka

$$
\left\{\left[P_{i}-P_{0}\right]_{\sim} \in \tilde{H}_{0}(X) \mid i=1,2, \cdots, n\right\}
$$

membentuk basis untuk $\tilde{H}_{0}(X)$.

Bukti. Mengingat karena penggantian operator batas hanya pada dimensi nol, maka $\tilde{H}_{k}(X)=H_{k}(X)$ untuk setiap $k \geq 1$. Akan dibuktikan persamaan (2.1) membentuk basis untuk $\tilde{H}_{0}(X)$. Dimulai dengan menunjukkan $\left\{\left[P_{i}-P_{0}\right]_{\sim} \in \tilde{H}_{0}(X) \mid\right.$ $i=1, \ldots, n\}$ adalah bebas linier. Asumsikan

$$
\sum_{i=1}^{n} \alpha_{i}\left[\hat{P}_{i}-\hat{P}_{0}\right]_{\sim}=0, \text { dimana } \alpha_{i} \in \mathbb{Z} .
$$

Maka, ada sebuah rantai $c \in \tilde{\mathcal{C}}_{1}(X)=\mathcal{C}_{1}(X)$ sedemikian sehingga

$$
\sum_{i=1}^{n} \alpha_{i}\left(\hat{P}_{i}-\hat{P}_{0}\right)=\partial c
$$


yang mana dapat ditulis kembali menjadi

$$
\sum_{i=1}^{n} \alpha_{i} \hat{P}_{i}-\left(\sum_{i=1}^{n} \alpha_{i}\right) \hat{P}_{0}=\partial c .
$$

Kelas homologi biasa, diperoleh

$$
\sum_{i=1}^{n} \alpha_{i}\left[\hat{P}_{i}\right]-\left(\sum_{i=1}^{n} \alpha_{i}\right)\left[\hat{P}_{0}\right]=0 .
$$

Akan ditunjukkan $\left[P_{i}-P_{0}\right]_{\sim}$ untuk $i=1,2, \cdots, n$ membangun $\tilde{H}_{0}(X)$. Misalkan $c$ sebuah siklik yang tereduksi pada dimensi 0 . Maka, secara khusus, $c \in \tilde{C}_{0}(X)$. Ada $b \in \tilde{C}_{1}(X)$ sedemikian sehingga $c=c^{\prime}+\tilde{\partial}_{1} b$. Karena $c$ adalah siklik yang tereduksi, maka diperoleh $\epsilon(c)=0$. Disisi lain,

$$
\begin{aligned}
\epsilon(c) & =\epsilon\left(c^{\prime}+\partial_{1} b\right) \\
& =\epsilon\left(c^{\prime}\right)+\epsilon\left(\partial_{1} b\right) \\
& =\epsilon\left(\sum_{i=0}^{n} \alpha_{i} \hat{P}_{i}\right) \\
& =\sum_{i=0}^{n} \alpha_{i} .
\end{aligned}
$$

Oleh karena itu, $\Sigma_{i=0}^{n} \alpha_{i}=0$, yang mana memperlihatkan bahwa $c^{\prime}$ adalah siklik yang terduksi juga. Maka, $0=-\sum_{i=1}^{n} \alpha_{i} \hat{P}_{0}$ dan dapat ditulis

$$
\begin{aligned}
c^{\prime} & =\sum_{i=0}^{n} \alpha_{i} \hat{P}_{i}-\sum_{i=0}^{n} \alpha_{i} \hat{P}_{0} \\
& =\sum_{i=0}^{n} \alpha_{i}\left(\hat{P}_{i}-\hat{P}_{0}\right) .
\end{aligned}
$$

Jadi,faktanya $c-c^{\prime}$ adalah sebuah batas, level homologi yang tereduksi. Diperoleh

$$
[c]_{\sim}=\left[c^{\prime}\right]_{\sim}=\sum_{i=0}^{n} \alpha_{i}\left[\hat{P}_{i}-\hat{P}_{0}\right]_{\sim} .
$$

\section{Kesimpulan}

Misalkan $X$ adalah himpunan kubik, grup homologi berdimensi $k\left(H_{k}(X)\right)$ dari ruang topologi $X$ dan grup homologi yang tereduksi yang berdimensi $k\left(\tilde{H}_{k}(X)\right)$. Diperoleh bahwa

$$
H_{k}(X) \cong \tilde{H}_{k}(X) \text {, dimana } k \neq 0
$$

Kemudian jika himpunan titik-titik $\left\{P_{i} \mid i=1,2, \cdots, n\right\}$ pada $X$ yang terdiri atas satu titik dari masing-masing connected component pada $X$, maka

$$
\left\{\left[P_{i}-P_{0}\right]_{\sim} \in \tilde{H}_{0}(X) \mid i=1,2, \cdots, n\right\}
$$

membentuk suatu basis untuk $\tilde{H}_{0}(X)$. 


\section{Ucapan Terima kasih}

Penulis mengucapkan terima kasih kepada Bapak Budi Rudianto, M.Si, Bapak Dr. Ahmad Iqbal Baqi, Ibu Nova Noliza Bakar, M.Si dan Ibu Dr. Yanita yang telah memberikan masukan dan saran sehingga paper ini dapat diselesaikan dengan baik.

\section{Daftar Pustaka}

[1] Bartle, R.G. dan D.R. Sherbert. 2000. Introduction to Real Analysis. Third Edition. USA: Copyright Act.

[2] Herstein, I. N. 1999. Topics in Algebra. Second Edition. John Wiley and Sons, New York.

[3] Jacob, Bill. 1990. Linear Algebra. W. H. Freeman and Company. New York.

[4] Kaczynski. T, K. Mischaikow, M. Mrozek. 2000. Algebraic Topology : A Computational Approach. New York.

[5] Kaczynski. T, K. Mischaikow, M. Mrozek. 2004. Computational Homology. Springer-Verlag New York.

[6] Min Yan. 2010. Topology. Hongkong University of Science and Technology. Hongkong. 